\title{
Alaska Fisheries and Global Trade: Red King Crab, Paralithodes camtschaticus; Sockeye Salmon, Oncorhynchus nerka; and Walleye Pollock, Gadus chalcogrammus
}

\author{
MICHAEL DALTON and JEAN LEE
}

\section{Introduction}

Fisheries have always been global based on the ecology of stocks. In addition, the real value of fish-related world exports has grown at an average rate of nearly $4 \%$ each year over the past three decades (Fig. 1), according to fisheries data from the Food and Agriculture Organization of the United Nations $\left(\mathrm{FAO}^{1}\right)$. The growth in real value reflects a global trend in the physical volume of fish-related exports (i.e., metric tons), which according to FAO data ${ }^{1}$, increased by more than $5 \%$ per year on average for the world over this period (Fig. 2). Together, these trends imply that prices, or the species composition of global catch and pro-

${ }^{1}$ FAO fisheries data include global export, import, and production data. These data were retrieved in May 2014 (www.fao.org/fishery/ statistics/software/fishstat/en).

Michael Dalton (michael.dalton@noaa.gov) and Jean Lee are with the Alaska Fisheries Science Center, National Marine Fisheries Service, NOAA, 7600 Sand Point Way NE, Seattle, WA 98115. The findings and conclusions in the paper are those of the authors and do not necessarily represent the views of the National Marine Fisheries Service, NOAA.

doi: dx.doi.org/10.7755/MFR.77.3.7

ABSTRACT-Wholesale revenues for seafood products from Alaska's red king crab, Paralithodes camtschaticus; sockeye salmon, Oncorhynchus nerka; and walleye pollock, Gadus chalcogrammus, fisheries in Alaska were greater than \$2 billion dollars in 2012 and more than half of this amount came from exports. Globally, red king crab from Alaska competes with red king crab from Russia, and market prices are highly variable. Alaska's walleye pollock producers also compete duction, or both, have changed in the past three decades. This article briefly evaluates these trends in the context of Alaska's commercial red king crab, Paralithodes camtschaticus; sockeye salmon, Oncorhynchus nerka; and walleye pollock, Gadus chalcogrammus, fisheries.

\section{Red King Crab}

The Bering Sea red king crab fishery has been the subject of much attention in recent years. The major world producers of red king crab are currently the United States and Russia, with Russia the main source of U.S. imports. According to FAO data ${ }^{1}$, Russia's production of king crab was historically much higher (Fig. 3). In 2007, U.S. producers ${ }^{2}$ confronted a large volume of relatively inexpensive

${ }^{2}$ Data on Alaska ex-processor values and quantities are based on fish ticket reporting and Commercial Operator Annual Reports (COAR) administered by the State of Alaska. The analysis in this article is based on COAR data retrieved from the Alaska Fisheries Information Network (www.akfin.org) in May 2014, before price data for 2013 were available. Consequently, the time series for Alaska end in 2012. Records in COAR data were summed for red king crab; golden king crab, Lithodes aequispinus; and blue king crab, $P$. platypus, to form a time series for all king crab to match the level of aggregation in U.S. trade data, which do not identify king crab to species.

with Russian producers, though prices are less variable than with king crab. The United States imports large amounts of farmed Atlantic salmon, Salmo salar, from Canada. In exchange, Canada was the top export destination for Alaska's sockeye salmon in 2012 and number two (after Japan) for Alaska's king crab. Wholesale prices for Alaska's sockeye followed import prices of farmed Atlantic salmon from Canada until 2008, and then increased relative to import prices. imports $^{3}$ of Russian king crab (Fig. 4). This situation is an economic problem for U.S. producers because cheap imports can cause a decline in wholesale (i.e., producer) prices ${ }^{4}$ for Alaska's king crab domestically and abroad, which benefits U.S. consumers but may reduce industry profits (Fig. 5).

Since 2006, average prices in real dollars for king crab have rebounded to previous peaks, demonstrating the variability of global and domestic prices for king crab. The downward trend in U.S. prices that started after 2002 occurred during a period of decline in Russian production and before the rise in U.S. imports, which occurred after 2004. Factors other than the total amount of crab on the market, such as the international composition of demand, must therefore be considered to explain recent trends in market prices.

Maps showing U.S. export destinations of king crab back to 1983 may be viewed online. ${ }^{5}$ All U.S. king crab

${ }^{3}$ Data on U.S. exports and imports were taken from the Merchandise Trade Statistics administered by U.S. Census Bureau based on 10-digit harmonized system (HS) codes for seafood commodities. These data were retrieved from the Trade Policy Information System (TPIS, tpis.trade.gov) in September 2013 and May 2014. These data record exports from each U.S. customs district (e.g., Anchorage, Seattle) to partner countries.

${ }^{4}$ The term "price" is used loosely in this article and refers to one of various price indices that are used. Each is defined generally as the sum of revenues over a set of fish (or crab) products (e.g., whole fish or fillets) divided by the total weight of those products (i.e, unit-value). Real values including prices are calculated using a producer price index (commodities) from the U.S. Bureau of Labor Statistics, series WPU0223, Unprocessed and packaged fish (http://www.bls.gov/ppi). The base year is 2012 for all real values.

${ }^{5}$ Maps in this article are the frame for year 2012 taken from a set of dynamic maps showing U.S. exports over time in metric tons of Atka mack- 


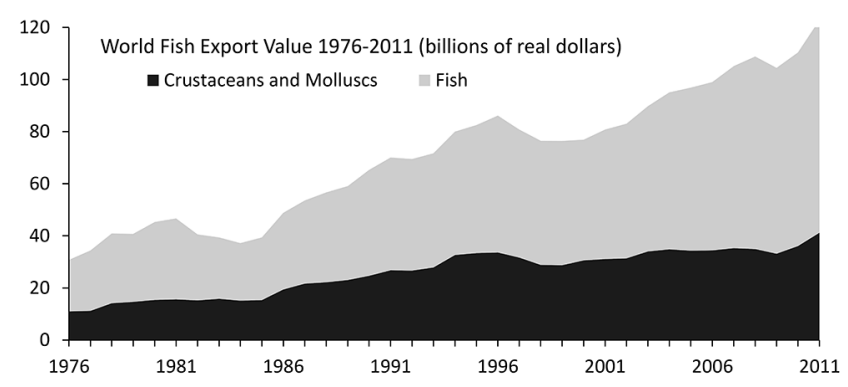

Figure 1.-World export value of crustaceans, mollusks, and fish (Source: FAO).

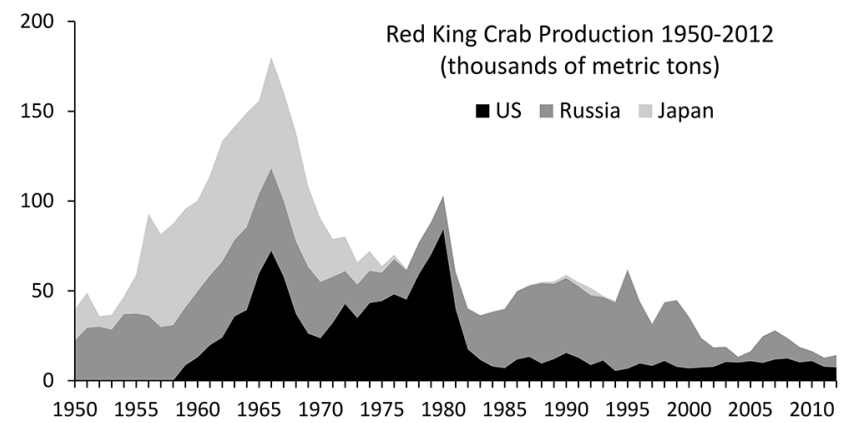

Figure 3.-World production of red king crab (Source: FAO).

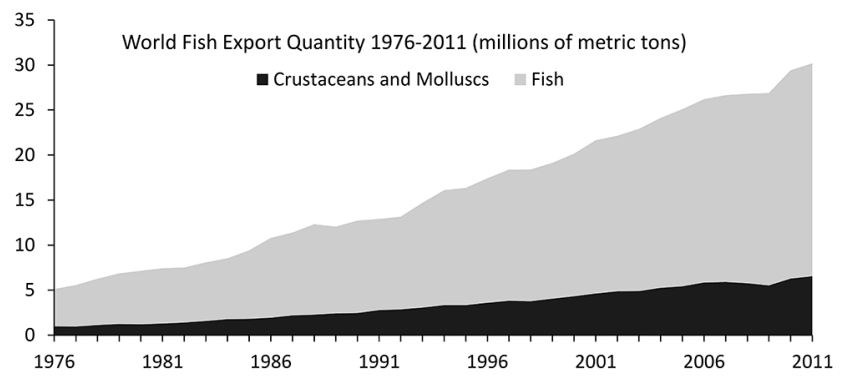

Figure 2.-World export quantity of crustaceans, mollusks, and fish (Source: FAO).

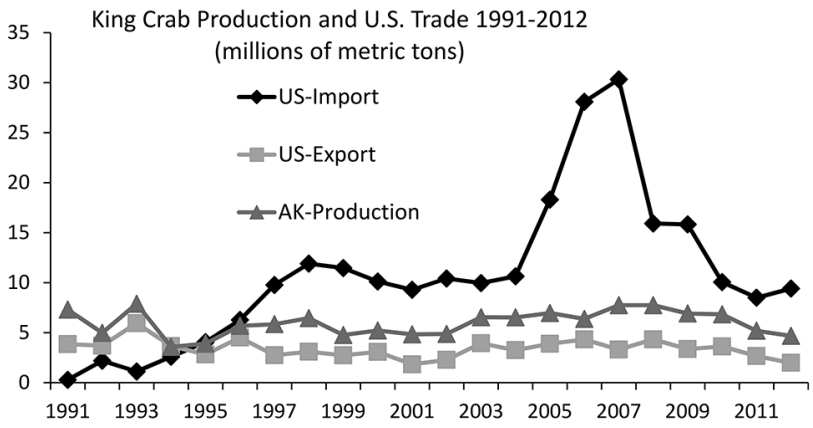

Figure 4.-Alaska king crab production and U.S. trade (Source: COAR, TPIS).

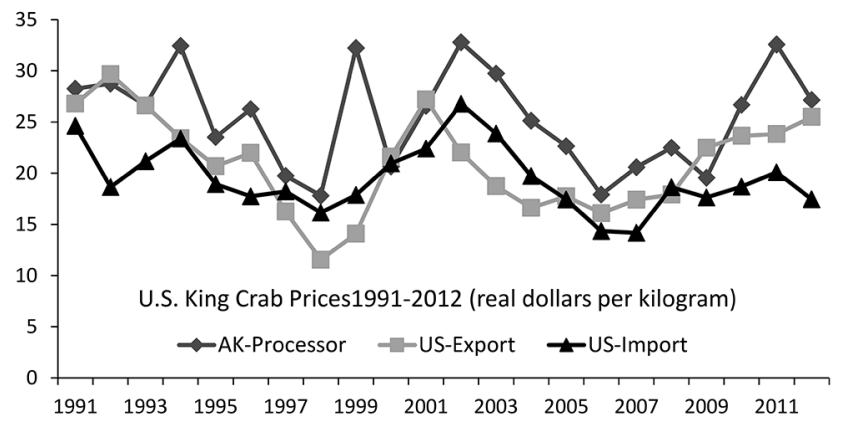

Figure 5.--U.S. king crab prices (Source: COAR, TPIS).

erel, Pleurogrammus monopterygius; red king crab; Pacific ocean perch, Sebastes alutus; rock sole, Lepidopsetta bilineata and L. polyxystra; sablefish, Anoplopoma fimbria; sockeye salmon; walleye pollock; and yellowfin sole, Limanda aspera. Animations of these dynamic maps for U.S. exports of Alaska seafood products are presented online (www.afsc.noaa.gov/REFM/ Socioeconomics/Projects/AFGT.php). The starting year of each animation depends on the year the relevant HS code was created. For king crab, sockeye salmon, and walleye pollock, the starting year is presented in the titles of Figure 6, 11 , and 16 , respectively. For example, TPIS has trade statistics for king crab going back to 1983. Note that exports to Canada in these maps are represented by the port of Come By Chance in the province of Newfoundland and Labrador. is harvested off the coast of Alaska. In 2012, the majority of U.S. exports of king crab were shipped via Anchorage and Seattle mainly to Japan, Canada, China, and Europe, with smaller amounts shipped to tourist areas in Southeast Asia and the Caribbean (Fig.

This choice was deliberate. Locating import symbols at the better known port of Vancouver, Canada, interfered with export symbols for Seattle. Likewise, locating symbols at the port of Toronto interfered with export symbols for U.S. customs districts close to the border (e.g., New York).
6). The overall picture shows that large quantities of Alaska king crab are shipped all over the world, with major markets in Asia, Canada, and Europe providing a valuable source of income.

\section{Sockeye Salmon}

The United States is a major producer of wild Pacific salmon which includes Chinook, O. tshawytscha; chum, O. keta; coho, O. kisutch; pink, O. gorbuscha; and sockeye salmon (Fig. 7). Alaska has the largest salmon 


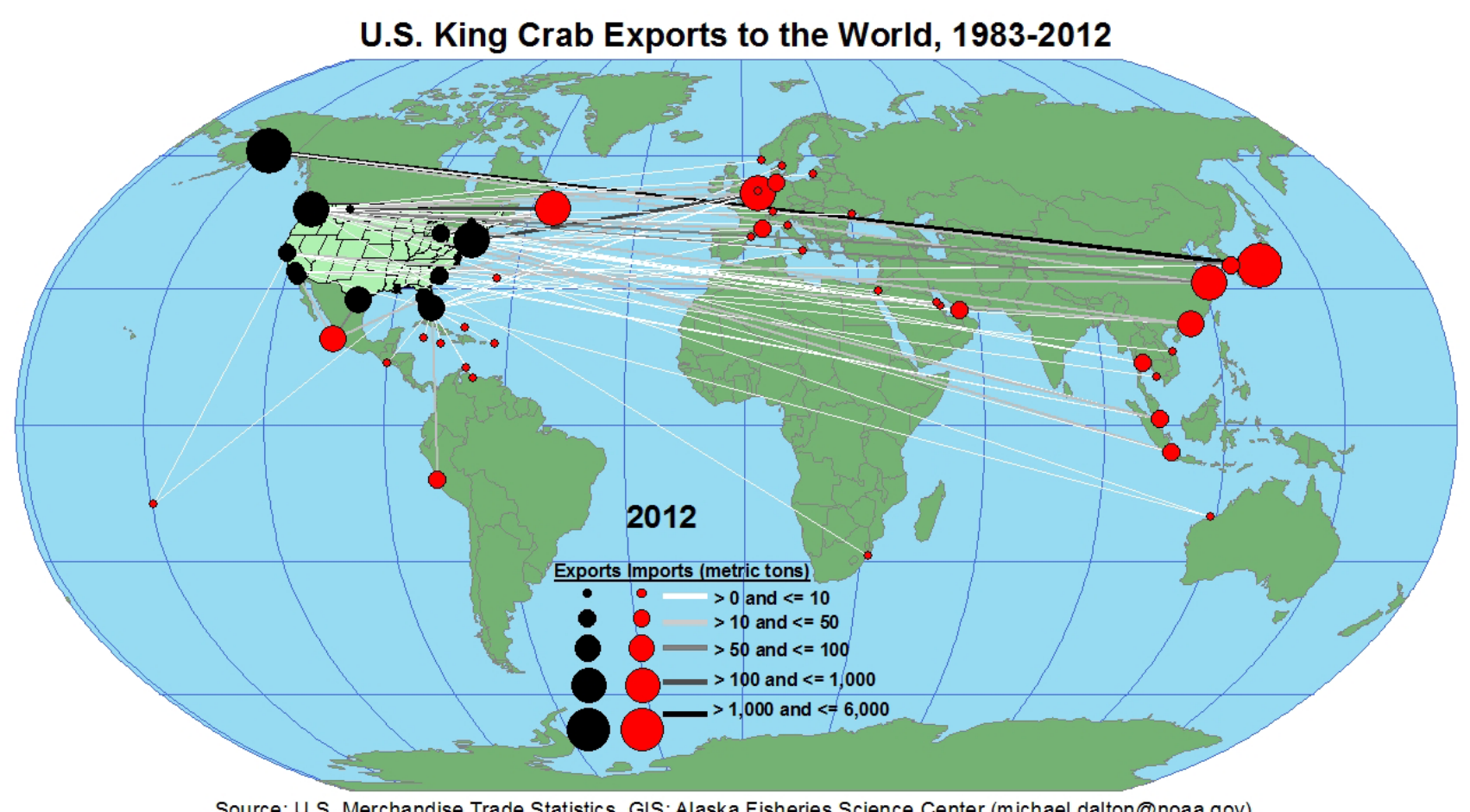

Source: U.S. Merchandise Trade Statistics, GIS: Alaska Fisheries Science Center (michael.dalton@noaa.gov)

Figure 6.-U.S. king crab exports to the world in 2012 (Source: TPIS time series from 1983-2012).

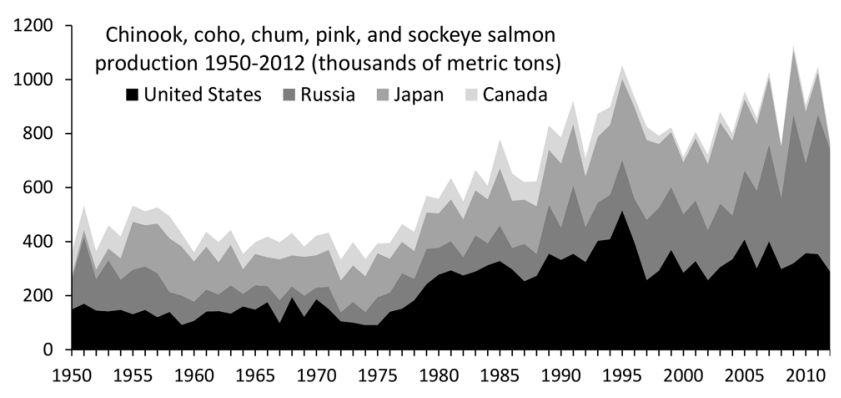

Figure 7.-Global wild salmon production (Source: FAO).

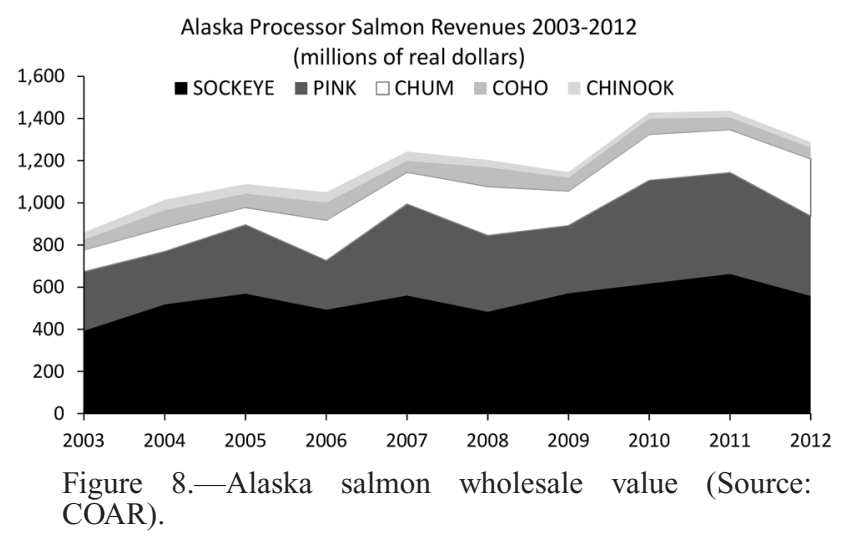

production of any state, and much of Alaska's revenues come from sockeye (Fig. 8). In terms of total revenue in Alaska from a single species, sockeye salmon ranks second behind walleye pollock.

The United States imports large quantities of farmed Atlantic salmon, mainly from Canada (Fig. 9). Wholesale prices for Alaska sockeye have tracked prices for U.S. imports of farmed Atlantic salmon, but recently these price series diverged (Fig. 10). In 2012, the majority of U.S. exports of sockeye salmon were shipped via Anchorage and Seattle mainly to Japan, Canada, and Europe (Fig. 11).

Canada has been the main source of farmed Atlantic salmon imported by the United States (Fig. 9), as well as a major consumer of Alaska sockeye salmon (Fig. 11), and Alaska king crab (Fig. 6). In 2012, Canada was the top destination for U.S. exports of fresh and frozen sockeye salmon, with over a quarter of the export volume (Fig. 11). In addition, one-fifth of U.S. exports of frozen king crab went to Can- ada (Fig. 6). This exchange of farmed salmon for wild salmon and crab presents an interesting pattern of trade between the United States and Canada.

\section{Walleye Pollock}

Real wholesale revenues for Alaska's processors from walleye pollock averaged nearly $\$ 1.4$ billion per year from 2003 to 2012, close to three times more than sockeye salmon, the species with the second highest revenues during this period (Fig. 12). Globally, the United States was the top pollock 


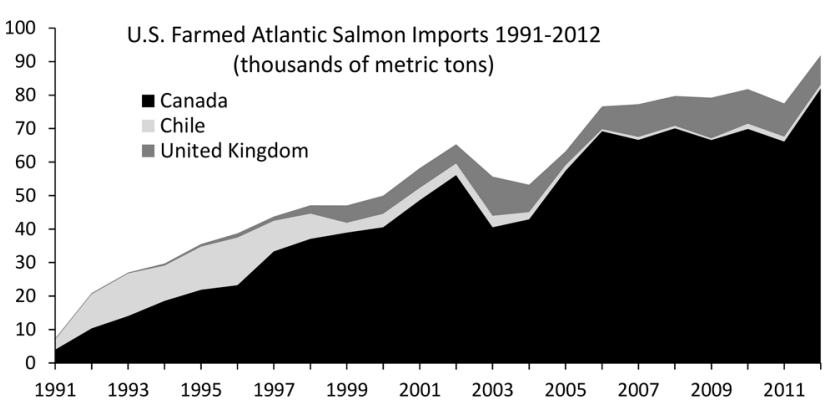

Figure 9.-U.S. imports of farmed Atlantic salmon (Source: TPIS).

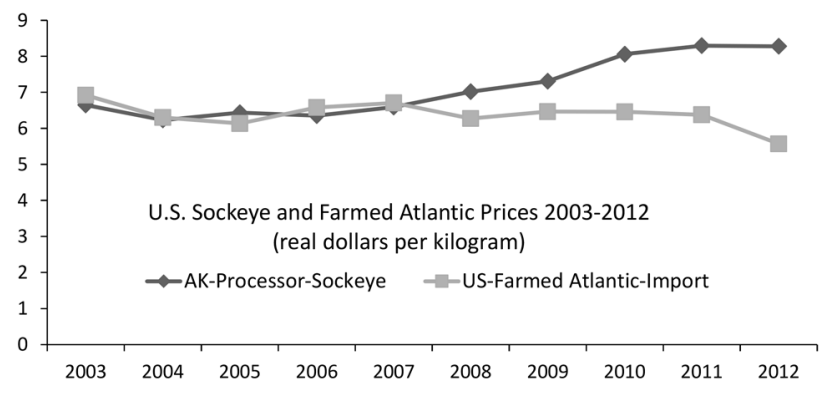

Figure 10.-Prices for Alaska sockeye and U.S. farmed Atlantic salmon imports (Source: COAR, TPIS).

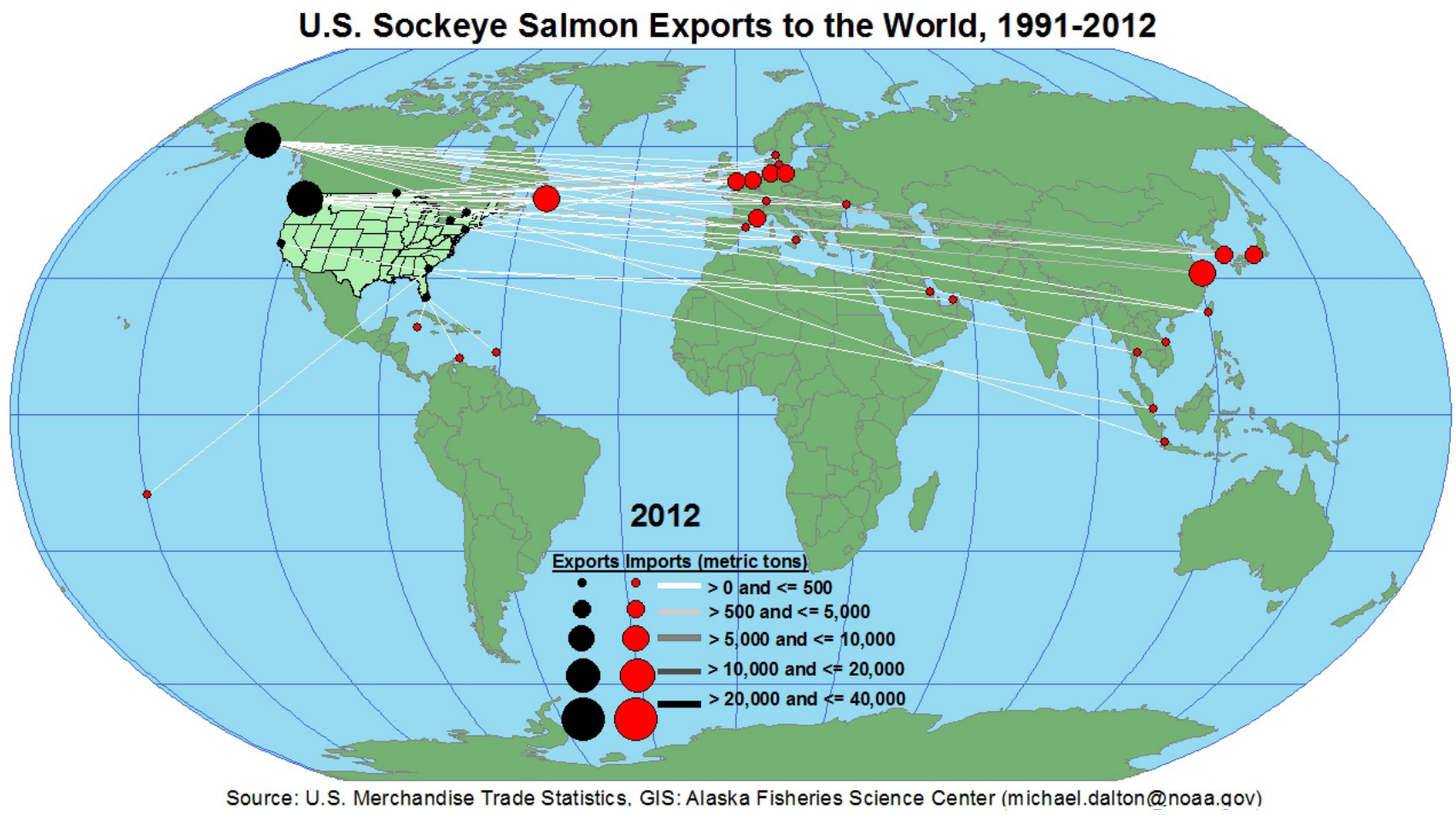

Figure 11.-U.S. exports of sockeye salmon to the world in 2012 (Source: TPIS time series from 1991-2012).

producer between 2000 and 2008, but, historically, Russia has produced more (Fig. 13). The three main products of Alaska pollock are fillets, roe (eggs), and surimi (paste). Production and exports of each product decreased after 2007 (Fig. 14). Prices for roe have declined since 2003, while prices for fillets and surimi have fluctuated without exhibiting a clear trend (Fig. 15). The global distribution of U.S. exports of walleye pollock (Fig. 16) shows the importance of markets in Asia and Europe (and, to a lesser extent, Canada) in the international demand for seafood products from Alaska.

\section{Conclusions}

This article describes the historical role and recent state of global markets in Alaska red king crab, sockeye salmon, and walleye pollock fisheries.
In the first case, Alaska crab was seen to compete directly with the Russian crab industry, which historically has had high production levels and exports to the United States.

The second case compared wholesale prices received by processors of Alaska sockeye salmon to the global rise in farmed Atlantic salmon. In this case, the United States was seen to export about half of its wild sock- 
Top-Ten Alaska Processor Revenues 2003-2012(billions of real dollars)

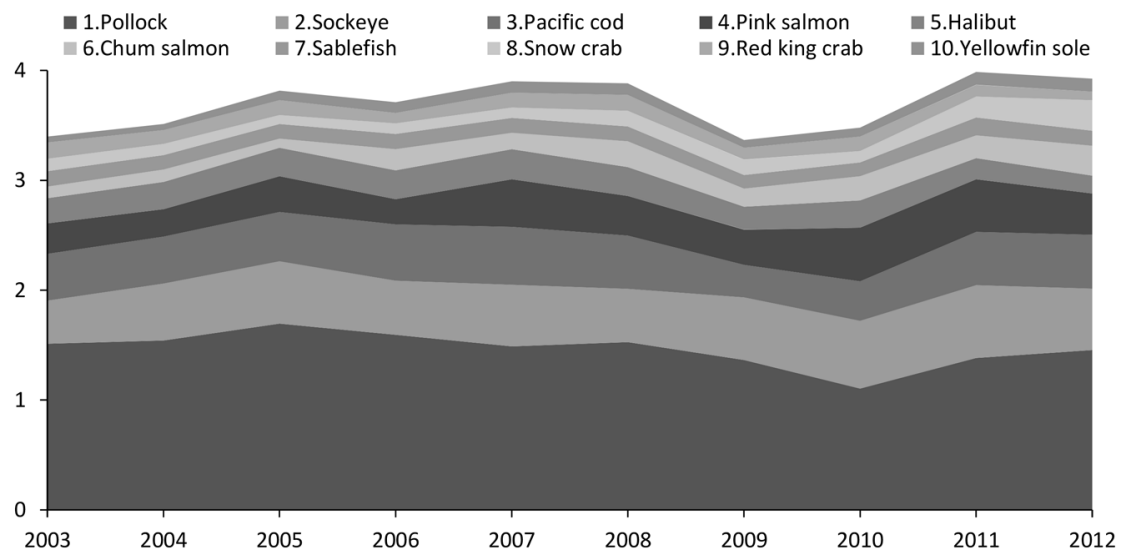

Figure 12.-Alaska top-ten species by wholesale value (Source: COAR).

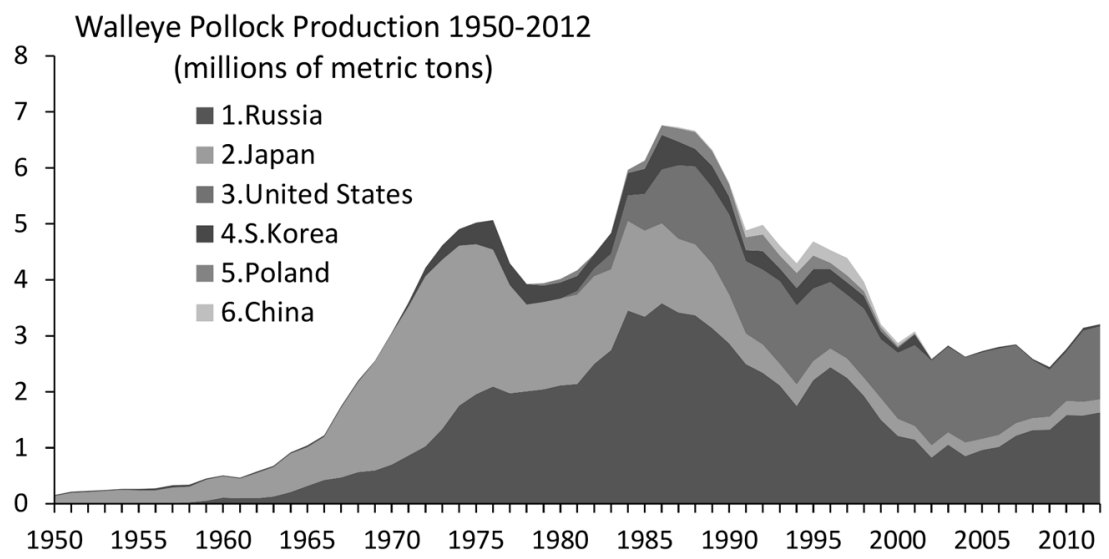

Figure 13.-World walleye pollock production (Source: FAO).

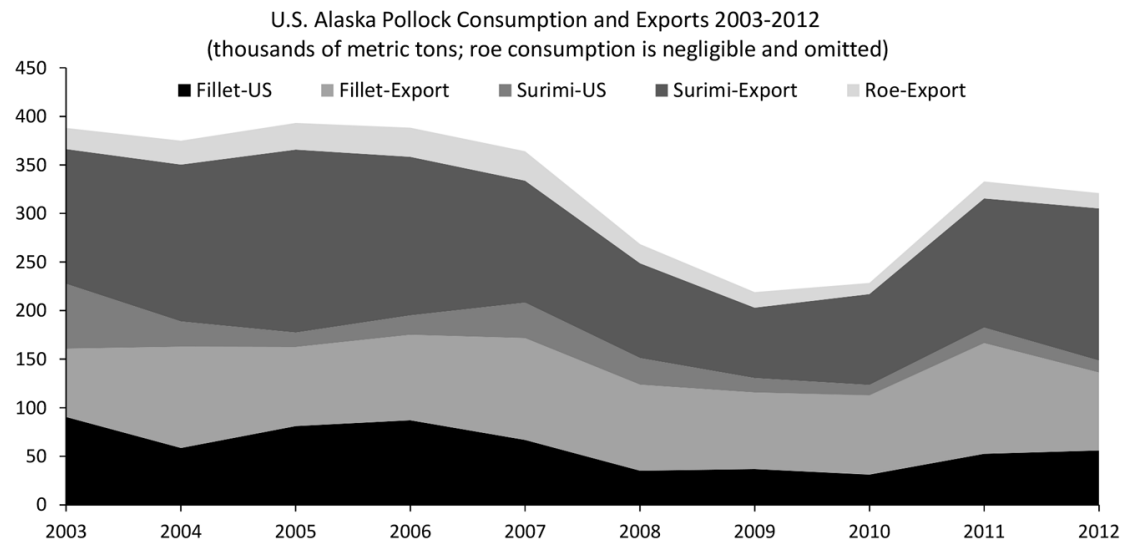

Figure 14.-U.S. consumption and exports of walleye pollock (Source: COAR, TPIS). 


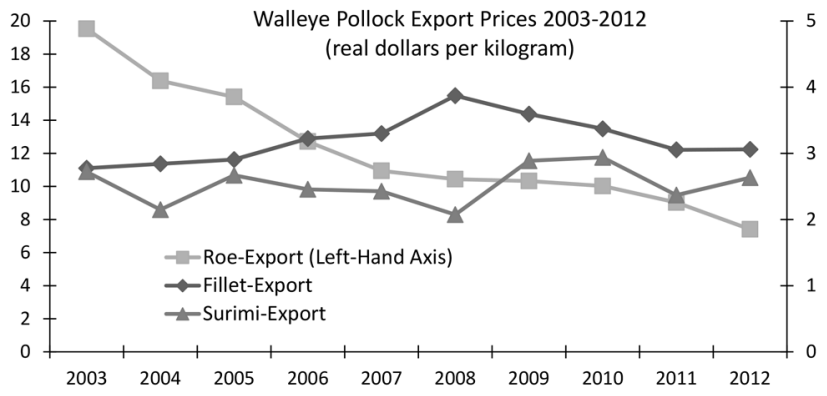

Figure 15.-Prices for exports of Alaska walleye pollock (Source: TPIS).

\section{U.S. Alaska Pollock Exports to the World, 1983-2012}

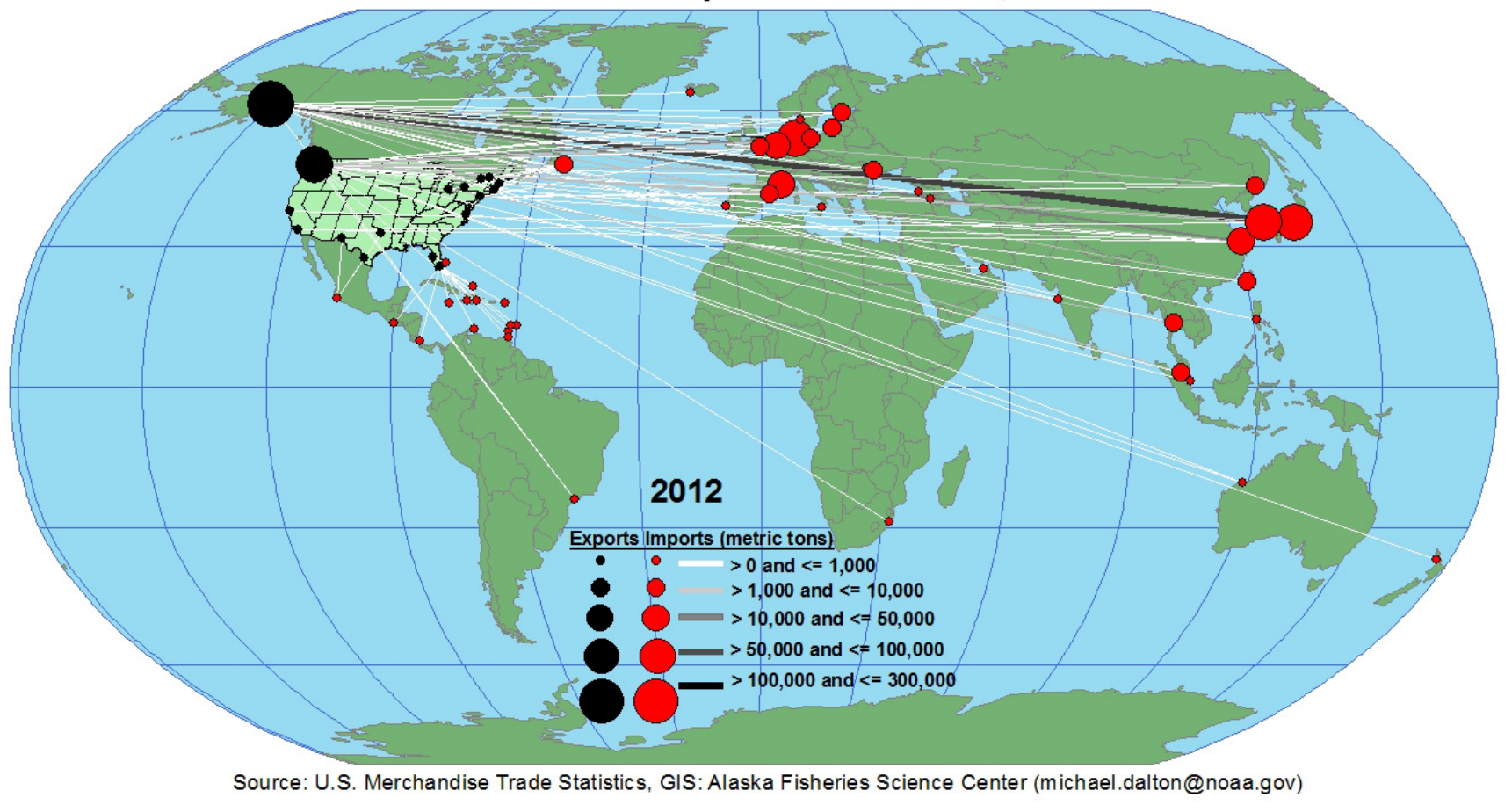

Figure 16.-U.S. exports of Alaska walleye pollock to the world in 2012 (Source: TPIS time series from 1983-2012).

eye production, with much of it going to Canada in exchange for imports of farmed Atlantic salmon. These commodities were exchanged at roughly equal prices until 2008, when U.S. producer prices for sockeye began increasing relative to import prices for farmed Atlantic salmon.

The third case gave a brief overview of the interrelated markets for fillets, surimi, and roe from walleye pollock. In each case, global trade and interna- tional market conditions played an important role. The historical relationship between sockeye prices and imports of farmed Atlantic salmon, as well as the variability in prices of red king crab and roe from walleye pollock, are additional evidence of effects of global markets on Alaska fisheries.

Although the global trend in seafood markets has been towards more exports, both sockeye and red king crab production in the United States are ex- ceptions. The share of exports in U.S. sockeye production has been fairly stable, fluctuating between $40 \%$ and $50 \%$ of production since 2003. The U.S. export share of king crab does not exhibit a trend since 2003 and has been highly variable, fluctuating as much as $40-70 \%$ in consecutive years; the average share for 2003-12 was slightly less than $60 \%$.

Walleye pollock roe is a low volume/high value product, and nearly all 
of it is exported. The U.S. export share of surimi production climbed from less than $70 \%$ in 2003 to over $90 \%$ in 2012. Japan is the main export market for roe and surimi, and fillets are shipped mainly to Europe and Canada, plus a variety of smaller markets in Asia, Africa, and Latin America. Export shares for fillets exhibited an up- ward trend during 2003-12, to about $60 \%$ in 2012 from less than $50 \%$ in 2003.

International trade is an important part of the Alaska economy, and crab, salmon, and groundfish fisheries all contribute. The future directions of these fisheries will probably be diverse, but trends in global seafood markets seem certain to be a common influence.

\section{Acknowledgments}

The authors thank two anonymous reviewers and the editor for many helpful comments. The primary author is responsible for any remaining errors. 